特 策 14

\title{
ストレス潰瘍の成因と外科治療成績
}

\begin{tabular}{|c|c|c|c|c|c|}
\hline \multicolumn{6}{|c|}{ 新潟大学第 1 外科 } \\
\hline 松原 & 要一 & 武藤 & 輝一 & 田宮 & 洋一 \\
\hline 磯部 & 茂 & 高桑 & 一喜 & 鰐㴊 & 勉 \\
\hline 田中 & 乙雄 & 奈良车 & 省吾 & & \\
\hline
\end{tabular}

\section{PATHOGENESIS AND SURGICAL TREATMENT OF STRESS ULCER}

\section{Youichi MATSUBARA, Terukazu MUTO, Youichi TAMIYA, Shigeru ISOBE, Kazuyoshi TAKAKUWA, Tsutomu WANIFUCHI, Otsuo TANAKA and Seigo NARAI}

The 1 st Department of Surgery, Niigata University School of Medicine

策引用語：ストレス潰煌，成因，外科治療

$$
\text { はじめに }
$$

脳疾患や肝・胆道疾患などの外科手術後にしばしば 見られる上部消化管出血は，多くが胃・十二指腸，食 道の急性粘膜病変からのbので, いわゆるストレス潰 瘍として知られている1). その予後は原疾患が重篤で 合併症のあるものが多く，また潰瘍の成因が複雑でそ の治療が困難なこともあって極めて不良である、今回 これまでに教室で経験したストレス潰瘍症例の治療成 績を検討し, 治療上の問題点について若干の知見を得 たので報告する。

\section{I ストレス溃瘍症例}

1976年より1981年まで 6 年間に76例のストレス潰瘍 症例を経験した，全例に下血あるいは吐血などの消化 管出血が認められたが, 穿孔例が十二指腸潰瘍で 4 例, 胃潰瘍で 1 例計 5 例にみられた. 穿孔例は比較的稀で, 表 1 に示したように原疾患が重篤で全身状態が不良な うえ，ほとんどが意識障害などのため穿孔による腹膜 炎の診断が遅れたこともあって 1 例も救命されなかっ た. 症例の 1 のみ救命の機会があったと思われるが術 後合併症で失った。他の 4 例は根治的な外科治療が施 行できず，外科治療以前の原疾患に対する治療と，穿 孔性腹膜炎の早期診断が当面の問題であることを示し

※第19回日消外総会シンポII 急性胃粘膜病変 (AGML)
ている。したがって穿孔例は出血例と分けて検討しな ければならない。

出血例は71例で，年齢は 1 歳から78歳，40６0歳代 が多く，男性50例，女性21例であった。これらの原疾 患は这疾患が最も多く, 次いで肝・胆道疾患, その他 の消化器疾患，心疾患などで，これに手術侵襲や意識 障害, 腹膜炎, 肺炎, 胆道感染, 腎不全, 閉塞性黄病, 心不全などの何らかの重篤な合併症が加わってスト レッサーとなっていた（表 2 ）。

初発症状は全例が消化管出血で，下血が55\%，胃管 内出血が $29 \%$ ，吐血が19\%に久られたが，潰瑒部位が 十二指腸の場合では吐血はみられずほとんどが下血で あった。

ストレス発生より出血するまでの期間（平均士標準 偏差）は，保存療法のみを行った39例では11士14日と バラッキがみられたが，手術療法を行った29例では $8 \pm 4$ 日で，10日前後のものが多かった.

出血量をみると, $1000 \mathrm{ml}$ 以下のるのは 24 例 (34\%), 1000 2000ml が13例 (18\%)，2000ml を超古るすのが 34例（48\%）で大量出血を来たすものが多かった，平 均すると保存療法のみ施行例では $1500 \pm 1900 \mathrm{ml}$ に対 乙, 手術療法施行例では $3800 \pm 1800 \mathrm{ml}$ と出血量が多 かった.

潰瘍発生部位は病変が確認できた 56 例でみると，胃 病変が十二指腸病変より多くみられ，十二指腸病変は 
表 1 ストレス潰瘍穿孔症例

\begin{tabular}{|c|c|c|c|c|c|c|c|c|c|c|}
\hline No. & 年齢 & 性 & ストレッサー & 発生まで & $\begin{array}{l}\text { 初発 } \\
\text { 症哭 }\end{array}$ & 輸血量 & 病変部位 & 手 術 & 予後 & 備 考 \\
\hline 1 & 17 & $\hat{\delta}$ & 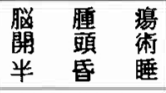 & 13日 & $\begin{array}{l}\text { 腹暯 炎 } \\
\text { 凅管出 }\end{array}$ & $1500 \mathrm{ml}$ & $\mathrm{B}^{*}$ & $\begin{array}{l}\text { 広胃切 B II } \\
\text { catheter } \\
\text { duodenostomy }\end{array}$ & 11 死目 & $\begin{array}{l}\text { duod. 断端 } \\
\text { 狿合不全穿孔 } \\
\text { 胆のう到 }\end{array}$ \\
\hline 2 & 19 & 우 & 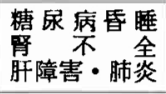 & 30 日 & $\begin{array}{l}\text { 腹芐膜 炎 } \\
\text { 血 }\end{array}$ & $800 \mathrm{ml}$ & $\mathrm{Pb} *$ & ドレナージ & $\underset{\text { 死 }}{65 \text { 日 }}$ & B 再穿孔 \\
\hline 3 & 40 & $q$ & $\begin{array}{l}\text { 临内出 } \\
\text { 血開 } \\
\text { 半 昏 睡 }\end{array}$ & 7 日 & 血 & $1200 \mathrm{ml}$ & $\mathrm{B}^{*} \mathrm{~Pb} *$ & $\begin{array}{l}\text { 試験開腹 } \\
\text { 生 検 }\end{array}$ & 術中死 & $\begin{array}{l}\text { acute necrotic } \\
\text { duod. ulcer }\end{array}$ \\
\hline 4 & 75 & $q$ & 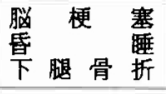 & 12日 & 血 & $1200 \mathrm{ml}$ & $A * B, P b$ & $\begin{array}{l}\text { 幹迷切 } \\
\text { 楼扬除 }\end{array}$ & 5 旦目 & $\begin{array}{l}\text { 脳罜死 } \\
\text { A B }{ }^{2} \text { 再穿孔 }\end{array}$ \\
\hline 5 & 26 & $\hat{\delta}$ & 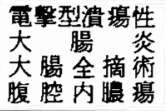 & 40日 & 血 & $3000 \mathrm{ml}$ & $\begin{array}{l}\mathrm{M} * \\
\mathrm{~B}, \mathrm{~Pb}\end{array}$ & $(-)$ & 5 旦目 & $\begin{array}{l}\mathrm{M} \text { 穿旮 } \\
\mathrm{B} \text { ，急性潰伢 }\end{array}$ \\
\hline
\end{tabular}

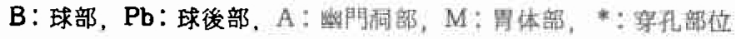

表 2 ストレス潰瘍症例の原疾患およびストレッサー

1. 脳疾患 37 例

脳内出血 14 (6)，クモ膜下出血 $13(10)$, 脳腫場 10 (3)

〔意識障害 22 , 開頭術 17 , 肺炎 7，消化管癌 2 , 堅不全 1 ，糖水病 1]

2. 肝・胆道宛患術後 13 例

恶性腫瘍 8(2), 胆石症 4(2)，外傷 $1(0)$

[閉塞性黄底 6 , 腹膜炎 4 , 肝硬変 2 , 胆管炎 1 ,

肺炎 1，出血性ショック1]

3. その他の消化器笑患術後 8 例

大腸澺 $2(1)$, 小腸壊死 $2(0)$, 穿孔性胃潰埸 1 (1)

穿孔性虫垂炎 $1(0)$ ，先天性食道閉鎖 $1(0)$ ，脾腫

$1(0)$

〔腹膜炎 5 , 堅不全 1 ，呼吸不全 1 ，髄膜炎 1 ， 骨髄線維症 1]

4. 開心術後 4例

先天性心疾患 2(1)，心臟弁膜症 2(0)

(心不全 4，腎不全 3，呼吸不全 2)

5. その他 9 例

整形外科術後 $3(3)$, 泌㽞器科術後 $2(0)$, 心筋梗

塞 $1(0)$, 再生不良性貧血 $1(0)$, 重症筋無力症

1(0), SLE 1 (0)

[腎不全 2, 心不全 2]

（）：手術㞠法施行例数

非脳疾患に比べ脳疾患に多かった。胃病変は胃角部か ら噴門部に多く,十二指腸病変は球後部に多かった(表 3 ).

潰瘍の性状を手術療法を行った29例でみると，胃病 変の20例中 Ul I II が14例, Ul III が 6 例で浅いわの が多く, 十二指腸病変の 5 例之共存病変の 4 例計 9 例 中Ul I〜II はみられず, U1 II〜III が 5 例, Ul III〜IV
が 4 例と深いものが多かった. 潰湯数は前者で $1 \sim 2$ 個が 2 例， $3 \sim 6$ 個が 11 例， 7 個以上が 5 例で 3 個以 上の多発例が多かったが，後者では 1 個が 1 例， 2 個 が 7 例， 3 個が 1 例と少なかった。

\section{II 治療成綨}

\section{i ）保存療法の成績}

病変部位別に止血効果をみると，胃病変で $43 \% ， 十$ 二指腸病変で $14 \%$, 共存病変で $22 \%$ が止血され, 十二 指腸病変の止血率が低かった（表 3 ).

出血量が $2000 \mathrm{ml}$ 以下のものとそれを超えるものに 分けてみると，前者では37例中28例 (76\%) が止血さ れたのに対し，後者では34例中 5 例（15\%）しか止血 されず，出血量が多くなると止血されにくかった。

血管露出の無いものと有るすのに分けると, 前者で は32例中22例 $(69 \%)$ が止血されたが後者では27例中 2 例（7\%）乙か止血されず血管露出があると止血さ れにくかった。血管䈞出の有った 27 例中 22 例は $2000 \mathrm{ml}$ を超える出血がみられ 1 例も止血されなかった。

止血に要した期間を29例の止血例でみると 2 日以内 が16例， 7 日までが 9 例， 8 日以上が 7 例で， 2 日以 内に止血されるものが多かった。

保存療法により71例中33例 $(46 \%)$, 約半数が止血さ れたが、このうち8 例 $(24 \%)$ は原疾患あるいは合併 症が悪化して死亡した。非止血例の38例中28例に緊急 手術が施行されたが他の 2 例は出血多量で死亡し， 8 例は原疾患が悪化して死亡した(表 4 )。したがって保 存療法の死亡率は $42 \%$ であったが，仮に非止血例に手 術が施行されなかったとすると源とんどが死亡したと 考えられるためその死亡率は65\%近くになると考学ら 
表 3 出血例の病変部位と止血例〔止血例数/症例数，（）:止血率〕

\begin{tabular}{|c|c|c|c|c|c|c|c|c|c|c|}
\hline 部位 & \multicolumn{4}{|c|}{ G } & \multirow{2}{*}{$\mathrm{E}+\mathrm{G}$} & \multicolumn{3}{|c|}{ D } & \multirow{2}{*}{$G+D$} & \multirow{2}{*}{$\mathrm{E}+\mathrm{G}+\mathrm{D}$} \\
\hline 疾患 & A & $\mathrm{AM}$ & $\mathrm{MC}$ & $\mathrm{AMC}$ & & B & $\mathrm{Pb}$ & $\mathrm{B}+\mathrm{Pb}$ & & \\
\hline $\begin{array}{c}\text { 脳疾患 } \\
\text { 33列 }\end{array}$ & 0 & 0 & $6 / 18$ & 0 & $2 / 2$ & $1 / 2$ & $0 / 2$ & $0 / 3$ & $1 / 5$ & $1 / 1$ \\
\hline $\begin{array}{c}\text { 非脳疾患 } \\
23 \text { 例 }\end{array}$ & $1 / 1$ & $1 / 1$ & $3 / 11$ & $3 / 6$ & $1 / 1$ & 0 & 0 & 0 & $0 / 1$ & $0 / 2$ \\
\hline 小計 & $1 / 1$ & $1 / 1$ & $9 / 29$ & $3 / 6$ & $3 / 3$ & $1 / 2$ & $0 / 2$ & $0 / 3$ & $1 / 6$ & $1 / 3$ \\
\hline 計 & \multicolumn{4}{|c|}{$17 / 40(43 \%)$} & & \multicolumn{3}{|c|}{$1 / 7(14 \%)$} & \multicolumn{2}{|c|}{$2 / 9(2296)$} \\
\hline
\end{tabular}

$\mathrm{G}$ : 胃, $\mathrm{A}$ : 幽門洞部, $\mathrm{M}$ : 胃体部, $\mathrm{C}$ : 噴門部, $\mathrm{D}:$ 十二指腸, $\mathrm{B}:$ 球部, $\mathrm{Pb}$ : 球後部 $\mathrm{E}:$ 腹部食道

表 4 保存療法の成績

\begin{tabular}{c|c|c|c|c|c|c}
\hline \multirow{2}{*}{} & \multirow{2}{*}{ 症例数 } & \multicolumn{2}{|c|}{ 止血例 } & \multicolumn{3}{|c}{ 非止血例 } \\
\cline { 3 - 7 } & & 生存 & $\begin{array}{c}\text { 非出 } \\
\text { 血死 }\end{array}$ & 出血死 & $\begin{array}{c}\text { 非出 } \\
\text { 血 }\end{array}$ & 手術 \\
\hline 脳 疾 患 & 37 & 9 & 6 & 2 & 1 & 19 \\
\hline 非脳疾患 & 34 & $16 *$ & 2 & 0 & 7 & 9 \\
\hline 計 & 71 & 25 & 8 & 2 & 8 & 28 \\
\hline
\end{tabular}

(*止血後手術施行 1例)

止血率 $46 \%(33 / 71)$, 止血例死亡率 $24 \%(8 / 33)$

保存㙩法死亡率 42\%

表 5 手術成績

\begin{tabular}{c|c|c|c|c}
\hline \hline & 例数 & 生 存 & 非出血死 & 再出血死 \\
\hline 脳 疾 患 & 19 & 11 & 5 & 3 \\
\hline 非脳疾患 & 10 & 5 & 5 & 0 \\
\hline 計 & 29 & 16 & 10 & 3 \\
\hline
\end{tabular}

止血率 $90 \%(26 / 29)$

手術死亡率 $45 \%(13 / 29)$

れる。

ii）手術療法の成績

手術療法は保存療法で止血されなかった28例と，止 血されたが再出血の危険があると考えられた 1 例の計 29例に施行された（表 5 ).

出血より手術までの期間は 1 ～ 3 日が17例， $4 \sim 7$ 日が 4 例，8〜11日が 4 例，12 19日が 4 例で期間の 短いものが多かった.

施行された手術々式は胃病変の20例では，広範囲胃 切除が 2 例, 胃亜全摘兼幹迷切が 16 例, 胃全摘が 2 例 で, 十二指腸病変の 9 例では広範囲胃切除が 1 例, 胃 亜全摘兼幹迷切が 8 例であった（表 6，7）.

術後再出血は 3 例にみられたが, 胃病変の 1 例は胃 覀全摘兼幹迷切術後重篤な肺炎を併発し腹壁哆開を来 たし全身状態が悪化して消化管出血で死亡した。十二
表 6 胃病変に対する手術々式と予後

\begin{tabular}{|c|c|c|c|c|c|}
\hline & & 例数 & 生存 & 非出血死 & 再出血死 \\
\hline \multicolumn{2}{|c|}{ 広範囲胃切除 } & 2 & 1 & 1 & 0 \\
\hline \multicolumn{2}{|c|}{ 胃要全摘兼幹迷切 } & 16 & 8 & 7 & $1^{*}$ \\
\hline \multirow[t]{2}{*}{ 胃 } & 全摘 & 2 & 1 & 1 & 0 \\
\hline & 計 & 20 & 10 & 9 & 1 \\
\hline
\end{tabular}

* 腹壁哆開再手術後16日目下血

表 7 十二指腸病変に対寸る手術々式と予後

\begin{tabular}{|c|c|c|c|c|}
\hline & 例数 & 生 存 & 非出血死 & 再出血死 \\
\hline 庆範团胃切除 & 1 & 0 & 0 & $1 * 3$ \\
\hline 胃要全摘兼幹迷切 & $8^{* 1}$ & $6 * 2$ & 1 & $1 * 4$ \\
\hline 計 & 9 & 6 & 1 & 2 \\
\hline \multicolumn{5}{|c|}{ 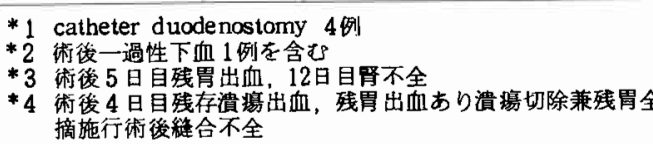 } \\
\hline
\end{tabular}

指腸病変の 2 例中 1 例は広範囲胃切除術後の残胃出血 があり腎不全で死亡，\&51例は胃亚全摘兼幹迷切術 後空置した潰瘍出血および残胃出血がみられ，潰瘍切 除と残胃全摘を行ったが術後縫合不全で死亡した。こ れらは術後管理および手術々式の選択に若干の問題が あったように思われる。

手術死亡は再出血死の 3 例と非出血死の 10 例の計 13 例で，死亡率は45\%と高率であった，非出血死は胃病 変の 9 例之十二指腸病変の 1 例の計10例で, このうち 2 例は術後 1 力月位の死亡で原疾患が主な死因と考党 られるためやさを得ないが，他の 8 例は術後 2 週間以 内の手術合併症による死亡で，このうち 4 例は術後 2 日以内の早期に死亡していて手術適応に問題があった と思われる。 


\section{III 考察}

ストレス潰瘍に対する治療はストレッサーとなった 原疾患や合併症に対する治療と同時に，その主症状で ある出血に対する治療が重要である，大量出血を来た すものが多いためもともと不良な全身状態がさらに急 速に悪化するものが多いが，此血されれば潰湟は短期 間に治癒するものが多いため，李ず保存療法で輸血や 輸液を行い循環系を安定させ，止血をはかることが必 要とされる2!.

教室の磯部は脳外科手術直後（1～3 日目）や減黄 手術直後, 胸部外科手術直後では胃酸分泌能が亢進し ていることを認め潰瘍が発生しやすい状態にあると報 告した3).ストレス潰瘍はこのような状態に重篤な合 併症が加わりストレッサーとなって急激な循環障害な ぞで粘膜の防禦因子が減弱して発生すると考えられる わけで，その発生因子に胃酸分泌を無視することはで きない。また血液の凝固は出血部位の $\mathrm{pH}$ が低いと障 害されるため゙)胃潰瘍出血は止血されにくいことが特 徵とされている。したがってストレス潰瑒出血の治㞠 は胃酸分泌に対し積極的に対処することが必要で，胃 内容吸引や泠たい生理的食塩水にする胃内洗涤あるい は制酸剤の投与が行われる。最近では histamine $\mathrm{H}_{2}^{-}$ receptor antagonistである cimetidine や secretin 制 剤など強力な胃酸分泌抑制剂が次々と開発され使用さ れるようになり，その有用性が報告されている5．胃出 血例の 4 例に cimetidine $200 \mathrm{mg}$ を静注投与して胃液 を調べたところ前値平均 $3.6 \pm 1.4$ 胃液 $\mathrm{pH}$ は 2 時間

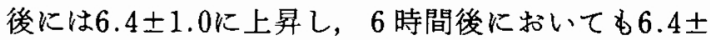
0.3 維持され, cimetidine が止血に有効に働くこと が示唆された。そこで1979年 6 月以降のストレス潰瘍 症例33例に cimetidine $200 \mathrm{mg} \times 4$ /日の投与を行いそ れ以前の非投与例38例と止血効果を比較してみた。 cimetidine 投与群の止血率が $61 \%$ なのに対し，非投与 群のそれは37\%であった。 また，止血例の止血に要し た期間をみると, 前者では19例中 7 例が24時間以内に, 4 例が25 48時間なのに対し後者では13例中それぞれ 1 例，4例であった。したがって cimetidine 投与によ り止血率が向上し，かつ止血例では早く止血される傾 向がみられた。しかし十二指腸病変や血管露出例, 大 量出血例では cimetidine を投与しても止血率は低く， 手術療法が必要とされる症例が多かった。

手術療法による止血効果は十分であるが，現在のと ころ手術死亡率が異常に高いためその適応は慎重に決 められなければならない，原疾患による死亡はやむを
得ないが，手術適応を早く決め，できれば内視鏡的に レーザーやアルコール注入などにより止血し出血量を 減らして手術を施行すれば手術合併症による死亡を减 らすことが可能であると考えている，現在ストレス潰 瘍に対する外科手術の適応は(1) 保存療法で止血され ないすの（血管露出, 大量出血, ショック, 十二指腸 病変では止血されにくい) (2) 原疾患（合併症を含む） の治療効果および予後が期待できるもの, (3) 外科手術 （胃切除術）に耐えられるもの（循環管理，呼吸管理， 栄養管理が可能なもの）などと考えている。

手術々式は術後潰瘍出血や残胃出血がないよ5, 原 則として潰湯を含めた胃切除が基本となる、したがっ て胃病変では多発性で高位のものが多いため，十分胃 切開を加え潰瘍の位置に応じて胃亜全摘兼幹迷切か胃 全摘を行 ${ }^{6 / 7)}$. 幹迷切はその手技が容易であると同時 に胃亜全摘を容易にする利点があるが，本来は手術例 の泳とんどがストレッサーからすぐには離脱できない ことと，胃切除術そのものが新たなストレッサーとな るため残胃出血を来たしやすい状態にあることから， その予防に必要と考之ている。十二指腸病変でも同様 の理由で胃垔全摘兼幹迷切を行う。しかし若年者で全 身状態や原疾患の予後が良好な場合は仮に再出血して も再手術ができるので広範囲胃切除でもよいかもしれ ない.十二指腸潰瘍は球後部に多いため，その妡除が 困難な場合は十二指腸切開を加え，出血部位の縫合止 血や血管の結禁，それに catheter duodenostomyによ るドレナージ，BII 吻合もやむを得ないと思われる。

\section{おわりに}

ストレス潰瘍の治療成績を示し，その治療上の問題 点について述べた，出血死を防ぐには手術療法を行わ ざるを得ないがその予後は不良である，手術成績を向 上させるためには内視鏡的に出血源を確認し手術適応 を゙早く決めることと，血管露出がある場合内視鏡的止 血を行い全身状態を悪化させないことが必要であろ

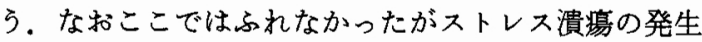
はある程度予測できるので，経鼻胃管による胃液吸引 や胃粘膜保護剤の注入, cimetidineなど強力な胃酸分 泌抑制剂の投与などで10日前後積極的に予防治療を行 うことが重要である.

\section{文 献}

1）亚木正義：急性胃潰愓の臨床一成因を中心にして 一。胃と腸 $23: 177-184,1978$

2) Menguy, R., et al.: The surgical management of acute gastric mucosal bleeding, stress ulcer, acute erosive gastritis and acute hemorrhagic 
gastritis. Arch Surg 99 : 198-208, 1969

3）磯部茂：ストレス潰場の成因と外科治療に関寸 了検討。日消外会誌 $14: 27-38,1981$

4) Green, F.W. Jr., et al.: Effect of acid and pepsin on blood coagulation and platelet ag. gregation. -A possible contributor to prolonged gastroduodenal mucosal hemorrhage. Gastroenterology $74: 38-43,1978$
5) Bubrick, M.P., et al.: Control of acute gastroduodenal hemorrhage with cimetidine. Surgery $84: 510-518,1978$

6）西村和夫, 光野孝雄：外科手術侵警とストレス潰 掦。ストレス潰掦 (並木正義編集). 新興医学出版 社, 東京, 1978, p132-144

7）武藤輝一, 磯部茂, 松木 久:ストレス潰場の治 療方針。消化器外科。 $2: 269-275,1979$ 